\title{
What is the most effective antecedent for developing entrepreneurial intention among Muslim youth in Indonesia?
}

\author{
Gunawan Baharuddin, Asmak Ab Rahman
}

\begin{abstract}
A B S T R A C T
Objective: The objective of the article is to examine the dominant antecedent (characteristic) for youth in Indonesia to become entrepreneurs, by using the theory of planned behaviour (TPB) model.

Research Design \& Methods: This work is a quantitative study with a deductive approach. It was conducted by surveying 727 undergraduate students from universities in Indonesia to measure both indicators for every construct (analysis factors) and correlation effects on other constructs (path analysis). All data obtained were analysed through partial least square structural equation modelling (PLS-SEM).

Findings: Among the three exogenous driver constructs, Subjective Norms has the strongest effect on Intention (0.152), followed by Perceived Behavioural Control (0.040) and Personal Attitude (0.011).

Implications \& Recommendations: Knowing the potential character of youth who become entrepreneurs enables policymakers to effectively plan targeted programs and policies. This article suggests several recommendations that focus on support from surrounding people such family, friends, and role models, who could approve young people's decisions to start own businesses.
\end{abstract}

Contribution \& Value Added: This research supports and strengthens the work of several researchers on the cultural and value factors that influence intentions with the additional element of religious values and virtues.

$\begin{array}{ll}\text { Article type: } & \text { research article } \\ \text { Keywords: } & \text { entrepreneurship; intention; youth; Theory of Planned Behaviour } \\ \text { JEL codes: } & \text { G41, L26, O15 }\end{array}$

Received: 7 May $2020 \quad$ Revised: 22 November $2020 \quad$ Accepted: 30 November 2020

\section{Suggested citation:}

Baharuddin, G., \& Ab Rahman, A. (2021). What is the most effective antecedent for developing entrepreneurial intention among Muslim youth in Indonesia?. Entrepreneurial Business and Economics Review, 9(1), 75-88. https://doi.org/10.15678/EBER.2021.090105

\section{INTRODUCTION}

In the new global economy, the youth has become an instrumental issue in the field of empowerment; accordingly, youth empowerment is extensively studied in fields such as education, health care, sociology, psychology, and economics. Youth empowerment enhances the development of citizens during their transition to adulthood (Jennings et al., 2006). This task creates job opportunities and is thus a priority for every nation.

Indonesia is currently experiencing a demographic bonus, by which the age of the productive population (15-64 years old) is double than that of the unproductive population (lower than 15 and over 65); this "bonus" will continue until 2035 (BPS, 2018). Meanwhile, the entrepreneurial sector in Indonesia proved its robust nature during the 1998 worldwide monetary crisis. Small and medium enterprises (SMEs) proved their resilience and ability to recover from the impact of that crisis quickly. This was because the SMEs base on domestic markets and provide employment for about 91.8 million people, or $97.3 \%$ of the labour force in Indonesia, and contribute as much as $53.6 \%$ to the gross domestic product (GDP; Azis \& Haerani, 2009). Due to these experiences, entrepreneurship has become the 
central focus of many stakeholders in Indonesia, including higher education institutions. Most universities now offer an entrepreneurship curriculum, and some have established dedicated departments to promote entrepreneurial culture (Mat, Maat, \& Mohd, 2015). Consequently, Indonesia has an increasingly encouraging atmosphere for entrepreneurship. Reports state that the growth ratio of SMEs was 14.92\% from 2010 to 2017, an increase of approximately 10 million SMEs (Ministry of Cooperatives and SMEs, 2018; Ministry of Cooperatives and SMEs, 2016). The owners of those SMEs are mostly aged 27-35, as reported by the Directorate of Cooperatives and SMEs Development (2016).

However, this is not an entirely positive situation because $11.41 \%$ of school graduates were unemployed at the time and not continuing their studies at a higher level (Indonesia Youth Statistic Report, 2017). Moreover, a survey reports that school leavers prefer employment in the government sector, followed by multinational companies and large domestic firms. Only a small fraction of youth is interested in starting their own business or finding a job in a small private domestic firm (Hutapea, 2017). Unemployment in 2018 amounted to seven million people in August 2018 compared to 6.87 million in February 2017 (Databoks, 2018). Based on this fact, this study will examine the youth perception to become entrepreneurs, especially university students after graduation. Previous studies imply that intentions towards entrepreneurial behaviour should explore more contextual factors to obtain better results and a broader perspective. Therefore, this study attempts to observe the dominant characteristics of Muslim youth in Indonesia in order to enhance our understanding of their entrepreneurial intention by using the theory of planned behaviour (TPB) model, along with the new latent variable of moral (religious) aspect included in intention variables.

To achieve its objective, this study employed an empirical approach using partial least square structural equation modelling (PLS-SEM) data analysis to measure the correlation between the tested variables: personal attitude, subjective norms, perceived behavioural control, and entrepreneurial intention. The TPB model is believed to provide a better explanation of how the development of entrepreneurial intention compared to other models. Likewise, PLS-SEM seemed most appropriate to measure the influence of each variable and the path relationship between the tested variables. Regardless of the object of study, Indonesia - with the largest Muslim population in the world - is a very significant sample for understanding the entrepreneurial intention of Muslim youth after graduation. Previous studies also use Indonesian student samples, e.g. Zamrudi and Yulianti (2020) and Patricia and Silangen (2016), but a specific focus on Muslim youth is rare.

The contribution of this article is twofold. Firstly, it enriches the literature of entrepreneurial intention using the theory of planned behaviour (TPB), particularly in Indonesia with the largest Muslim population in the world. The second contribution is empirical: while the TPB model is commonly used in this field, employing Muslim youth in the context of Indonesia provides a more extensive empirical perspective. The results of this study are expected to give a worthwhile perspective for reformulating entrepreneurship programs and curricula at Indonesian universities so that a stronger entrepreneurial culture can be created among the youth. In the Global Entrepreneurs Index (2018), Indonesia ranks 94th out of all 137 countries listed and seventh among the ASEAN countries.

The next sections and sub-sections are organised as follows. The literature review thoroughly discusses themes of entrepreneurial intention; models presentation and hypothesis development is the last part of the subsection. The third section discusses the methodological aspect of the empirical studies, including the development of the research instrument, the procedure to determine the sample from its population, and SEM-PLS as the tool for data analysis. The fourth section presents empirical results and discussion. The last section concludes with final remarks that review all the content of this research, how it can contribute, and the limitations of the study.

\section{LITERATURE REVIEW}

In recent years, studies about individuals and behaviour have emerged as an important approach for explaining the entrepreneurship phenomenon. Psychologists claim that intention effectively predicts subsequent behaviour (Ajzen, 1991), while some researchers substantiate that claim (Kolvereid, 1996b). Intention towards a behaviour reflects the motivation and enthusiasm of a person to perform 
the behaviour. Entrepreneurship is exactly a type of planned behaviour and there is vast literature discussing intention towards entrepreneurship.

Generally, entrepreneurship curricula are concerned with the development of entrepreneurial attitudes and inspiring creative thinking (Żur, 2014). Attitudes towards this behaviour refer to the degree to which the individual attaches a positive or negative personal value to being an entrepreneur (Ajzen, 2002). Interest in being an entrepreneur can be driven by many factors that vary among individuals: motivations of wealth, freedom, and personal autonomy (indicator level). Indeed, a number of studies conducted on students who partook in entrepreneurship classes or programs revealed that attitude is the strongest factor influencing their intention to start own businesses. Among such studies are Wibowo (2017), Husain (2017), Saheed and Kavoos (2016), Robledo et al. (2016), Soon, Rahman, and Nadia (2016), and Hussein (2015).

For subjective norm constructs, earlier studies often indicate that this antecedent fails to measure entrepreneurial intention (Autio et al., 2001; Krueger et al., 2000; Sparks \& Shepherd, 1992). However, Linan (2008) argues that the samples in those studies used are very socially homogeneous, thus generating a premature result. Among studies that support the argument of Linan is the one by Zamrudi and Yulianti (2020), who find that subjective norms are one of the main points that could increase a student's motivation to establish their own business. This study surveys both undergraduate and postgraduate student from 28 universities in Indonesia. Awang et al. (2016) study university graduates to find that to ensure more start-ups in Malaysia, serious attention should focus on their expectations of strong support from their university, family, friends, and peers, but also strengthening and reinforcing a proactive personality and risk-taking propensity. The agriculture faculty of Srilanka State University shows that subjective norms are the greatest factors influencing entrepreneurial intention (Wijerathna, 2015). The study by Yurtkoru, Kabadayı Kuşcu, and Doğanay (2014) finds that relational support is the most influential factor determining student entrepreneurial intention in Turkish universities. Similar studies find that individuals tend to be more influenced by the opinion of others (e.g. Moriano et al., 2011; Kolvereid, 1996; Tkachev \& Kolvereid, 1999).

These results follow the division of subcultures by Hofstede et al. (2010) that separates individualism and collectivism. In an individualistic subculture, attitudes become more important in shaping entrepreneurial intentions than social norms, in contrast to collective subcultures, in which social norms become very important when every individual has a strong orientation towards acceptance, approval, and conformity to their environment. Therefore, Indonesia can be classified as a collective group or communal culture. Hence, we may assume that social norms play an important role in the formation of entrepreneurial intentions in Indonesia. After all, some studies foreground that individualistic cultures generally fail to find an effect of social norms on entrepreneurial intention (Robledo et al., 2015; Dabic et al., 2012; Shiri et al., 2012).

Religion has also been linked to entrepreneurial intention as religiosity has a significant influence in shaping daily life decisions. The connection between entrepreneurship and religion is addressed in the context of all religious traditions (Deutschmann, 2001; Garvey, 2003; Klay \& Lunn, 2003). According to Pearce, Fritz, and Davis (2009), religions might promote acts of entrepreneurship. Similarly, Salimath and Cullen (2010) argue that levels of religiosity are positively related to entrepreneurial outcomes when moral virtues are pursued not for the sake of generating profit but as an end in themselves (Cheung \& King, 2004). Moreover, the Buddhist doctrine of right livelihood plays a significant role in evaluating and exploiting entrepreneurial opportunities (Valliere, 2008) as being a religious activity and striving to succeed in entrepreneurship is to give success in the afterlife (Lucky, 2011).

Some studies in Indonesia observe entrepreneurial intention among Muslim students using the TPB model. The work of Wibowo (2017) reveals that religious groups have stronger entrepreneurial intentions with lower dispersion than students who are not religious. The categorisation of religious or irreligious respondents was based on their view about the importance of religiosity in daily life. The lowest range of average for the irreligious group is less than or equal to 2 on a Likert scale, while the religious group averaged answers of 5 to 6 on a 7 Likert scale; those whose average value was around 2 to 5 on a Likert scale were categorised as swinging religious persons with an unstable view of the importance level of religiosity in daily life. Wibowo sampled 412 Muslim students at the Faculty of 
Economic and Business at the University of Indonesia. Another study by Rokhman and Ahamed (2015) of 300 undergraduates from four different faculties at the Islamic College of Kudus in Central Java, Indonesia, reveals that family background and social status are prominent and significantly influence the youth to become entrepreneurs. Therefore, the hypothesis to be tested in this study is:

H: Subjective norms are dominant antecedents that influence the entrepreneurial intention of Muslim youth in Indonesia.

This hypothesis is supported by Moriano et al. (2011) and Hofstede et al. (2010) who indicate that Indonesia tends to be a collective group or communal culture, in which social norms are an important factor in making daily decisions. However, religiosity makes people more independent, self-confident, and creative.

\section{RESEARCH METHODOLOGY}

\section{Instrument development}

This study employs an empirical study using an explanatory approach for the purpose of finding student intention regarding entrepreneurship. The theory of planned behaviour (TPB) is widely used to model the intention formation process and manifestation (Ajzen, 1991) not only in the field of entrepreneurship but also in other fields, such as consumption behaviour (Nejati et al., 2011), dental visits (Elyasi et al., 2020), physical activity among children (Wang \& Wang, 2015), and many other intention-based research.

Since the 1980s, there have been six major models to measure a person's intention to become an entrepreneur: (1) the entrepreneurial event model (EEM); (2) the entrepreneurial intention model (EIM); (3) the revised EIM with self-efficacy; (4) the theory of planned behaviour (TPB); (5) the economic-psychological model (EPM); and (6) the structural model of entrepreneurial intention (SMEI). From these, the EIM, EPM, and SMEI lack empirical tests for entrepreneurial studies, while the EEM, revised EIM, and TPB are the dominant intention models in the field (Tung, 2011). The revised EIM has received the least empirical support and is yet to be validated (Drnovsek \& Erikson, 2005), while the EEM and TPB models have been well tested. Although the mediating role of self-efficacy between background factors and intention has been well tested (Wilson, Kickul, \& Marlino, 2007; Zhao, Seibert, \& Hills, 2005), the entire revised EIM model has not been empirically tested. Therefore, the revised EIM is less appropriate than the other models. Furthermore, Tung (2011) explains that the revised EIM and EEM lack information on the factor of subjective norms. In the revised EIM and EEM, attitudes towards creating a new business are considered a broad concept wherein merge both personal and social factors that influence one's desirability or willingness. However, the TPB distinguishes between attitudes pertaining to personal interest or attraction regarding the entrepreneurial behaviour (personal level) and attitude due to social influence (social level). Such a separation of attitudinal antecedents is meaningful and necessary as it provides more detailed information than the other two models. Only the TPB extends the antecedents of entrepreneurial intention to a social level. The model includes a subjective norm factor, which is reflected in attitudes that arise from opinions of important people. This factor has a direct impact on entrepreneurial intention. Thus, the TPB provides a clearer picture of how entrepreneurial intention is formed, with a detailed basis on how to investigate the entrepreneurial intention of youth.

Three types of individual beliefs influence the process of intention: the beliefs in the consequences that may arise from an action (behavioural belief); the belief in the expectations of others (normative beliefs); the belief in the existence of certain elements that can inhibit the emergence of certain actions (belief control). Thus, these three factors of confidence produce intention factors such as personal attitudes, social norms, and perceived behavioural control.

The antecedents of personal attitude (PA), subjective norm (SN), and perceived behavioural control (PBC) are corresponding beliefs that reflect the underlying cognitive structure. These three motivational factors that influence behaviour are explained as follows. Attitude towards a behaviour refers to the degree to which the individual has a positive or negative personal valuation about being an entrepreneur (Ajzen, 2002; Kolvereid, 1996). Perceived social norms measure the perceived social 
pressure to conduct an entrepreneurial behaviour or not. Perceived behavioural control would be defined as the perception of the ease or difficulty in the fulfilment of a behaviour of interest (i.e. becoming an entrepreneur).

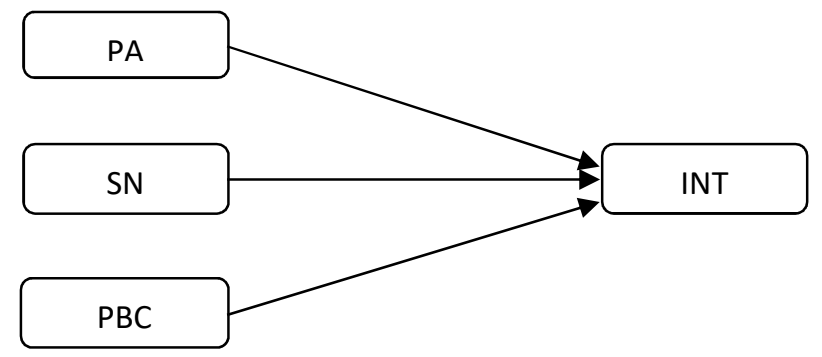

Figure 1. The Theory of Planned Behaviour Model by Ajzen

Note: PA - Personal Attitude; SN - Subjective Norm; PBC - Perceived Behavioural Control; INT - Intention. Source: Ajzen, 1991, p. 182.

The questionnaires in this study used seven-point Likert scales, ranging from "strongly agree" to "strongly disagree." The reason behind using a seven-point scale is that it reduces inaccuracy, provides more alternatives for respondents, and produces a less skewed distribution (Burns \& Bush, 2000). For personal attitude measurement, this study adopted construct questions from Shinnar et al. (2012), which uses four latent constructs under the exogenous driver of behavioural belief: autonomy, money, challenges, and life-work balance. For subjective norms measurement, this study adopted construct questions from Carsrud and Braannback (2011), with three dimensions of social norms: role model, entrepreneurial experience in the family, and environment support. Finally, for perceived behavioural control measurement, this study adopted construct questions from Muller (2009), in which four latent dimensions of the control belief - self-competency, business connection, capital, and government support - are asserted to construct this variable. The entrepreneurial intention was measured by six questions adapted from Linan and Chen (2009) with slight adjustment by incorporating virtue and moral aspects; for instance, "I want to be an entrepreneur so that I can help others by creating new jobs" and "[b]y becoming an entrepreneur I can freely worship and help others both materially and spiritually." Hence, 35 questions investigated the conviction of an individual towards venture creation.

In order to achieve the objective of this study, PLS-SEM seemed most appropriate because it can measure both indicators for every construct (analysis factor) and correlation effects on other constructs (path analysis).

\section{Sample and data collection}

Youth is best understood as a period of transition from the dependence of childhood to adulthood's independence. For statistical purposes, they are people between the ages of 15 and 24 years, without prejudice to other definitions by the member states of the United Nations (UN, 2019). Shinnar et al. (2012) state that a student sample is very suitable for the study of entrepreneurship intention because students directly face the problem of career options after graduation; during their university life, they are continuously considering various career possibilities.

This study set the age of youth between 19 and 24 years as the students in the sample who are currently studying at universities. The estimated population of Muslim students in Islamic universities all over Indonesia is 775 517, according to the Ministry of Religion Affairs (Indonesia Statistic Agency, 2015). Samples were determined by a purposive sampling method from the top five provinces with the highest number of Muslim students in Indonesia: East, West, and Central Java, South Sulawesi, and Aceh. Considering that the three former provinces are on the same island (Java), Central Java was chosen as representative of the middle part of Indonesia, South Sulawesi - the eastern part, and Aceh - the western part. By using the sample size table with a confidence level of $95 \%$ and a $5 \%$ margin of error, this research required the minimum of 663 students for an ideal sample. However, before the data was collected, a pilot study had been deployed with 153 samples from public universities in order to ensure that all the questions were valid and reliable. 
The data was collected through an online survey via Google forms. We obtained help from lecturers at selected universities in distributing questionnaires to their students. The lecturers distributed the online questionnaire in classes or via WhatsApp groups. However, questionnaire distribution before classes proved more effective than via WhatsApp Group because the lecturers could directly ask the students to complete the questionnaire. This method was quite effective and efficient for our study, ensuring 740 responses collected in just two months; although 13 were disregarded as invalid. In the end, 727 valid responses were available for this study.

\section{Data analysis}

Structural equation modelling comprises two phases of analysis: measurement analysis, which specifies the relationship between construct and indicator, and structural analysis, which determines the relationship between one construct to another construct. In the measurement analysis stage, validity allows for the assessment of the degree of measurement error, and it subsequently attempts to minimise any errors in the entire process of study (Pallant, 2011). In the structural measurement model, three main assessment criteria are necessary: internal consistency reliability, convergent validity, and discriminant validity.

Ramayah et al. (2018) suggest that using composite reliability for internal consistency reliability is more appropriate and applies to the accepted values range of 0.60-0.90. For the measurement of convergent validity, loading values (average variance extracted or AVE) equalled or were greater than 0.4, which was acceptable if the summation of loadings resulted in high loadings scores, contributing to AVE scores greater than 0.5 (Hulland, 1999). In the next stage of cross loading, Fornell Larcker's criterion and the Heterotrait-Monotrait Ratio of correlations (HTMT) were employed to measure discriminant validity. A few requirements were necessary for it to pass: loadings of each indicator should have been the highest for their designated constructs; the square root of average variance extracted (AVE) for a construct should have been greater than the correlation between the construct and other constructs in the model; and for HTMT criterion, if the value below 0.85 means that there is no discriminant issue between two reflective constructs. Further steps were applied to assess the structural model: checking for collinearity issues; the significance and relevance of the structural model relationship; and the coefficient of determination.

In this study, all data were screened for the assessment of the measurement analysis and the structural model. The structural model analysis required VIF values to equal 5 or more. Path coefficient values were standardised on a range from -1 to $+1, R^{2}$ aims to measure the accuracy of the model's prediction, where $0.26,0.13$, and 0.02 respectively described substantial, moderate and weak levels of predictive accuracy (Cohen, 1988; qtd. in Hair et al., 2017).

\section{RESULTS AND DISCUSSION}

With respect to gender, there were slightly more female (370) than male (357) respondents. According to Table 1, this study found that male students had slightly more entrepreneurial intention than female students, which was reflected in mean values of 36.21 compared to 35.92, respectively. In contrast with the personal attitude antecedent, young Muslim women had a higher mean value with 80.53 compared to 79.85 for men, which may indicate that young women hold a more positive personal valuation about being entrepreneurs. However, masculinity typically is a more likely attribute of an entrepreneurial professional (Shinnar et al., 2012; Diaz-Garcia \& Jimenez-Moreno, 2010).

For the remaining antecedents of intention - the subjective norm and perceived behavioural control - this study found insignificant differences between male and female students. This may indicate that social pressures and the perception of the ease of fulfilling behaviour equally motivate both genders to become entrepreneurs, which is shown by the mean value of 37.55 compared to 37.40 for subjective norm and the mean value of 50.21 compared to 50.14 for perceived behavioural control.

By using the Smart PLS application, $t$ values and $p$ values were obtained to measure the impact of observed constructs on the independent variable in this study. Figure 2 and Table 2 summarise the results of the data analysis. Since the significance level set in this study was $5 \%$, the critical $t$ values for 
a two-tailed test were thus $1.96(t>1.96)$ or - alternatively - by examining the $p$ value, which should have been lower than $0.05(p<0.05)$.

Table 1. Gender comparison on entrepreneurial intention and the TPB

\begin{tabular}{|l|c|c|c|}
\hline \multicolumn{1}{|c|}{ Construct } & Gender & Mean & Std. Deviation \\
\hline \multirow{2}{*}{ Intention } & Male & 36.21 & 31.60 \\
\hline \multirow{2}{*}{ Personal Attitude } & Female & 35.92 & 33.20 \\
\hline \multirow{2}{*}{ Perceived Behavioural Control } & Male & 79.85 & 6.699 \\
\hline \multirow{2yyy}{*}{ Subjective Norm } & Female & 80.53 & 6.051 \\
\cline { 2 - 4 } & Male & 50.14 & 8.815 \\
\cline { 2 - 4 } & Female & 50.21 & 8.020 \\
\cline { 2 - 4 } & Male & 37.55 & 3.036 \\
\hline
\end{tabular}

Source: own elaboration of SPSS output, 2019.

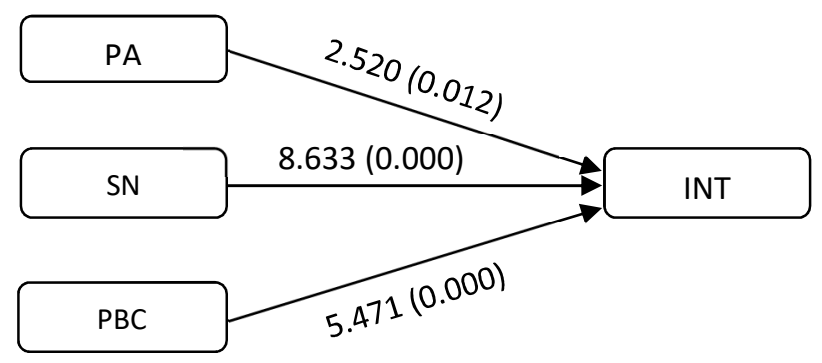

Figure 2. Model path assessment

Note: PA - Personal Attitude; SN - Subjective Norm; PBC - Perceived Behavioural Control; INT - Intention.

Source: own elaboration of Smart-PLS output, 2019.

Figure 2 illustrates that the path coefficient of personal attitude to intention has positive influence towards behaviour to become an entrepreneur, even though the effect size of personal attitude in this study was quite small (Table 3$)$ as revealed by the value of $p(0.012$, slightly below the threshold of 0.05 ) and its $t$ value (2.52, slightly above the threshold of 1.96$)$. This implies that personal attitude cannot determine the intentions of entrepreneurs. This result is similar with the work of Ridha and Wahyu (2017) and Arisandi (2016).

The second antecedent was subjective norms towards the entrepreneurial intention of youth. This result implies that subjective norm has a significant influence on their intention to start their own business, evidenced with the $t$ value of $8.633(>1.96)$ and $p$ value of $0.000(<0.05)$. This result is similar to that in Zamrudi and Yulianti (2020), Awang et al. (2016), and Wijerathna (2015).

Table 2. Structural analysis for TPB antecedents

\begin{tabular}{|c|c|c|}
\hline Path Analysis on Variables & T-statistics) |O/stdev|) & $p$-values \\
\hline $\mathrm{PA} \rightarrow$ INT & 2.520 & 0.012 \\
\hline $\mathrm{SN} \rightarrow$ INT & 8.633 & 0.000 \\
\hline $\mathrm{PBC} \rightarrow \mathrm{INT}$ & 5.471 & 0.000 \\
\hline
\end{tabular}

Note: PA - Personal Attitude; SN - Subjective Norm; PBC - Perceived Behavioural Control; INT - Intention.

Source: own elaboration of Smart-PLS output, 2019.

The third antecedent assessed the influence of perceived behavioural control on the entrepreneurial intention of youth. With the $t$ value of $5.471(>1.96)$ and $p$ value of $0.000(<0.05)$, the empirical analysis in this study confirmed that perceived behavioural control significantly influences the variable of entrepreneurial intention. This result suggests that an increase in young people's perceived selfefficacy towards self-employment will increase their entrepreneurial intentions. Moreover, research 
in this area has shown that the higher one's confidence in the ability to perform the behaviour necessary to be successful, the more one's behaviour will be influenced, which does not depend on what skills one possesses but on belief in one's abilities.

Therefore, with the above results, this study asserted that the proposed hypothesis is accepted, thus confirming the dominant antecedent that enhances the intention of Muslim youth to become entrepreneurs in Indonesia is subjective norms, followed by antecedents of perceived behavioural control and personal attitude. Entrepreneurial intention emerged as positively correlated with extraversion, openness, and the support of near people who are part of the subjective norm factor. Furthermore, the inclusion of this construct supports the social learning theory, which suggests that individuals are more likely to adopt behaviour observed in family and among close friends or from mentors, especially if the outcomes of such a behaviour are valued (Bandura, 1977).

The influence magnitude of the dependent variable on the independent variable can be seen from the measurement of $f^{2}$. Guidelines for assessing $f^{2}$ are that values of $0.02,0.15$, and 0.35 represent small, medium, and large effects (Cohen, 1988; qtd. in Hair et al., 2017) of the exogenous latent variable, respectively. Effect size values of less than 0.02 indicate that there is no effect. Therefore, among the three exogenous driver constructs, subjective norms have the strongest total effect on intention (0.152), followed by perceived behavioural control (0.040) and personal attitude (0.011). These results concur with the study conducted by Awang et al. (2016), which concludes that subjective norms and perceived behavioural control are the best predictors of entrepreneurial intention among students, and that the factor of attitude tends to be disqualified from the TPB model.

Table 3. Effect size for each construct

\begin{tabular}{|l|l|}
\hline \multicolumn{1}{|c|}{ Variables } & $f^{2}$ \\
\hline Personal Attitude & 0.011 \\
\hline Subjective Norm & 0.152 \\
\hline Perceived Behavioural Control & 0.040 \\
\hline
\end{tabular}

Source: own elaboration of Smart-PLS output, 2019.

This study shows Indonesian youth is having higher confidence in their ability to become future entrepreneurs. Other constructs under this antecedent, such as business assistance, access to capital, and government support, are believed to be easier accessible than before, and the government has more influence in this matter. Moreover, recent years have shown a positive development in financial access, namely crowdfunding, which is a method of connecting - through internet-based intermediary entities - entrepreneurs who want to increase their capital with investors who have funding sources. There were 14 active crowdfunding platforms in Indonesia in January 2020, consisting of 151 platforms that are conventional lending-based, while the rest are shariah lending-based (OJK, 2020). This shows that the development of funding platforms brings positive progress to the development of micro, small-sized and medium enterprises (MSMEs) in Indonesia.

\section{CONCLUSIONS}

This study focused on a specific context, and it was conducted to provide a better perspective and understanding of entrepreneurial intention among Muslim youth in Indonesia. Universities are expected to be the main driving force in creating effective programs to increase the intention of young people to start own businesses, be it independently or by cooperating with community organisations or the government. With the largest Muslim population in the world, Indonesia should be able to exploit this potential to develop strong, stable, and sustainable economic conditions. The higher the entrepreneurial activity, the more job opportunities for multiplier effects in the economy provide by stimulating consumption and production. According to the World Bank, the ideal level of entrepreneurship in Indonesia is $4 \%$ for it to become a developed country; its current total entrepreneurship is still roughly $1.6 \%$, compared to other ASEAN countries, such as Singapore, Malaysia, Thailand, which show levels of $7 \%, 5 \%$, and $4.3 \%$, respectively, with Vietnam and the Philippines being above $3 \%$. 
Therefore, this study opens a wider understanding regarding what factor is the most significant in increasing the youth's intention to become entrepreneurs, thus the gap in the number of entrepreneurs recommended by the World Bank can be minimised.

This study finds that subjective norms are the dominant factor among the three antecedents of the TPB model towards intention, followed by the factor of perceived behavioural control. The factor of subjective norms represents support from people such as family and friends, and it is the most effective factor for developing the entrepreneurial intention of Muslim youth. The antecedent of perceived behavioural control is the second-best construct, so concerns of self-competency, capital access, and government support have a significant impact in heightening the entrepreneurial intention of the youth. The government should provide incentives for those who are willing to form a start-up after graduating, such as free registration fees for business legal administration, managerial consultancy from practitioners or entrepreneurs, and capital assistance.

In accordance with the results presented in this study, the following are recommended for stakeholders in Indonesia to formulate effective programs and policies:

- Universities and the government should involve family members, in particular students' parents, to educate them that being an entrepreneur can be a promising profession with a bright future. The mindset of parents in Indonesia is generally for their children to become government employees or work in large private companies because this profession is considered to have a minimal risk of failure.

- Create a joint program between universities or government institutions and mosque organisation committees in each region to provide business incubator programs for Muslim youth. Financial aid also might come from charity funds or endowment of communities around mosques.

- Forming a team of fellow young Muslim entrepreneurs. As well as action at the university level, mosques can play a role in shaping the character of youth, not only in religious aspects but also in economic aspects, such as having an entrepreneurial character.

- Create programs for business start-up competitions between mosques so that they can stimulate creative ideas among the youth. Such a program also opens opportunities for financial access from the public.

- Create training and mentoring programs by start-up entrepreneurs who have successfully built their businesses from scratch to allow young people find role models that could continue to motivate them in building their own businesses.

This research also contributes to the sphere of knowledge and theory. Our results support and reinforce research into cultural and value factors that influence personal intentions. Moreover, contexts such as the Muslim youth population in Indonesia can be another avenue for future research, especially examining the driving factors towards intention enhancement.

This research does have several limitations. Firstly, it used Muslim youth in general to measure entrepreneurial intentions. Better and more precise results will be gained when specifically conducted for Muslim youth who took entrepreneurship courses at universities. Secondly, elements of religion and virtue inserted into the model were only partially included in the intention variable. This article recommends that future research use the variable of maqasid al-shariah ("the objective of Islamic law") as a mediator variable in the TPB model. There are five drivers under maqasid al-shariah for a Muslim to achieve well-being: faith, intellect, health, progeny, and wealth.

\section{REFERENCES}

Acs, Z.J., Szerb, L., Lafuente, E., \& Lloyd, A. (2018). Global Entrepreneurship and Development Index. Springer International Publishing. https://doi.org/10.1007/978-3-030-03279-1

Ahmad, M. (2014). Attitudes, Subjective Norms and Perceived Behavioural Control on Entrepreneurial Intention of Nigerian. Utara Malaysia University.

Ajzen, I. (1991). The Theory of Planned Behavior. Organizational Behavior and Human Decision Processes, 50(2), 179-211. 
Ajzen, I. (2002). Perceived Behavioural Control, Self-Efficacy, Locus of Control, and the Theory of Planned Behavior. Journal of Applied Social Psychology, 32(4), 1-20. https://doi.org/10.1111/j.1559-1816.2002.tb00236.x

Ajzen, I. (2005). Attitudes, Personality and Behaviour. Maidenhead, England: Open University Press, NY.

Ajzen, I., Czach, C., \& Flood, M.G. (2009). From Intentions to Behavior: Implementation Intention, Commitment, and Conscientiousness. Journal of Applied Social Psychology, 39(6), 1356-1372. https://doi.org/10.1111/j.1559-1816.2009.00485.x

Anggadwita, G., \& Dhewanto, W. (2015). Women's Entrepreneurial Intentions in Micro and small enterprises (MSEs) in Indonesia: The Influence of Environmental Factors on Perceived Behavioral Control. Journal of Administrative and Business Studies, 1(1), 1-7. https://doi.org/10.20474/jabs-1.1.1

Arisandi, D. (2016). Intensi Berwirausaha Mahasiswa Pascasarjana Institut Pertanian Bogor Pada Bidang Agribisnis (Studi Kasus Pada Mahasiswa Program Magister Sps-Ipb). IPB University.

Autio, E., Keeley, R.H., Klofstein, M., Parker, G.G.C., \& Hay, M. (2001). Entrepreneurial Intent Among Students in Scandinavia and in the USA. Enterprise and Innovation Management Studies, 2(2), 145-160. https://doi.org/10.1080/14632440110094632

Awang, A., Amran, S., Md Nor, M.N., Ibrahim, I.I., \& Razali, M.F. (2016). Individual Entrepreneurial Orientation Impact on Entrepreneurial Intention: Intervening Effect of PBC and Subjective Norm. Journal of Entrepreneurship, Business and Economics, 4(2), 94-129. Retrieved from https://www.researchgate.net/publication/292606501_INDIVIDUAL_ENTREPRENEURIAL_ORIENTATION_IMPACT_ON_ENTREPRENEURIAL_INTENTION_INTERVENING_EFFECT_OF_PBC_AND_SUBJECTIVE_NORM on August 20, 2020.

Azis, A., \& Haerani, A.R. (2009). Peranan Bank Indonesia di Dalam Mendukung Pengembangan Usaha Mikro, Kecil, dan Menengah (Kebanksent). Jakarta, Indonesia: Pusat Pendidikan dan Studi Kebanksentralan (PPSK).

Bandura, A. (1977). Social Learning Theory. Upper Saddle River, NJ: Prentice Hall.

Burns, A.C., \& Bush, R.F. (2000). Marketing Research. (8th Edition). Upper Saddle River, NJ: Prentice Hall.

Carsrud, A., \& Braannback, M. (2011). Entrepreneurial Motivations: What do we still need to know?. Journal of Small Business Management, 49(1), 9-26. https://doi.org/10.1111/j.1540-627X.2010.00312.x

Cheung, T.S., \& King, A.Y. (2004). Righteousness and profitableness: the moral choices of contemporary Confucian entrepreneurs. Journal of Business Ethics, 54(3), 245-260.

Cialdini, R., \& Trost, M. (1998). Social Influence: Social Norms, Conformity, and Compliance. In D.T. Gilbert, S. Fiske, \& G. Lindzey (Eds.), The Handbook of Social Psychology (pp. 151-192). Boston, MA: McGraw-Hill.

Cohen, J. (1988). Statistical Power Analysis for the Behavioural Science (2nd ed.). Hillsdale, NJ: Lawrence Erlbaum Associates.

Dabic, M., Daim, T., Bayraktaroglu, E., Novak, I., \& Basic, M. (2012). Exploring Gender Differences in Attitudes of University Students Towards Entrepreneurship: An International Survey. International Journal of Gender and Entrepreneurship, 4(3), 316-336. https://doi.org/10.1108/17566261211264172

Deutschmann, C. (2001). Capitalism as a religion? An unorthodox analysis of entrepreneurship. European Journal of Social Theory, 4(4), 387-403. https://doi.org/10.1177/13684310122225226

Diaz-Garcia, M., \& Jimenez-Moreno, J. (2010). Entrepreneurial Intention: The Role of Gender. International Entrepreneurship and Management Journal, 6(3), 261-283. https://doi.org/10.1007/s11365-008-0103-2

Drnovsek, M., \& Erikson, T. (2005). Competing Models of Entrepreneurial Intentions. Economic and Business Review, 7(1), 55-71. https://doi.org/10.1016/S0883-9026(98)00033-0

Ellis, K., \& Williams, C. (2011). Maximizing Impact of Youth Entrepreneurship support in Different Context. London: United Kingdom.

Elyasi, M., Lai, H., Major, P.W., Baker, S.R., \& Amin, M. (2020). Modelling the Theory of Planned Behaviour to predict adherence to preventive dental visits in preschool children. PLOS ONE, 15(1), e0227233. https://doi.org/10.1371/journal.pone.0227233

Franke, N., \& Lüthje, C. (2004). Entrepreneurial intentions of business students - A benchmarking study. International Journal of Innovation and Technology Management, 1(3), 269-288. https://doi.org/10.1142/S0219877004000209

Garvey, G. (2003). The theory of the firm, managerial responsibility, and catholic social Teaching. Journal of Markets \& Morality, 6(2), 525-540. Retrieved from https://papers.ssrn.com/sol3/papers.cfm?abstract_id=911576 on April 20, 2020. 
GEDI. (2018). Global Entrepreneurship Index Data. Retrieved from https://thegedi.org/2018-global-entrepreneurship-index-data/ on April 20, 2020.

Hair, J.F., Hult, T.M., Ringle, C.M., \& Sarstedt, M. (2017). A Primer on Partial Least Square Structural Equation Modeling (PLS-SEM). Sage Publications.

Hisrich, R. (1990). Entrepreneurship/Intrapreneurship. American Psychologist, 45(2), 209-222. https://doi.org/10.1037/0003-066X.45.2.209

Hofstede, G., Hofstede, G.J., \& Minkov, M. (2010). Cultures and Organizations: Software of the Mind (Rev. 3rd ed.). New York: McGraw-Hill.

Hulland, J. (1999). Use of Partial Least Square (PLS) in Strategic Management Research: A Review of Four Recent Studies. Strategic Management Journal, 20(2), 195-204. https://doi.org/10.1002/(SICI)10970266(199902)20:2<195::AID-SMJ13>3.0.CO;2-7

Indonesia Statistic Agency. (2017). Indonesia Youth Statistic Report. Jakarta, Indonesia.

Ismail, M., Khalid, S.A., Othman, M., Jusoff, H., Abdul, R.N., Kassim, K.M., \& Zain, R.S. (2009). Entrepreneurial intention among Malaysian undergraduates. International Journal of Business Management, 4(10), 54-60.

Jennings, L.B., Parra-Medina, D.M., Hilfinger-Messias, D.K., \& McLoughlin, K. (2006). Toward a Critical Social Theory of Youth Empowerment. Journal of Community Practice, 14(1-2), 31-55. https://doi.org/10.1300/J125v14n01_03

Kolvereid, L. (1996). Prediction of Employment Status Choice Intentions. Entrepreneurship Theory and Practice, 21(1), 47-58.

Klay, R., \& Lunn, J. (2003). The relations of god's providence to market economics and economic theory. Journal of Markets \& Morality, 6(2), 541-564. Retrieved from https://www.marketsandmorality.com/index.php/mandm/article/view/462 on April 20, 2020.

Krueger, N., Reilly, M., \& Carsrud, A. (2000). Competing Models of Entrepreneurial Intentions. Journal of Business Venturing, 15(5-6), 411-432. https://doi.org/10.1016/\$0883-9026(98)00033-0

Kuehn, K.W. (2008). Entrepreneurial Intensions Research: Implications for Entrepreneurship Education. Journal of Entrepreneurship Education, 11(1), 87-98.

Linan, F., \& Chen, Y.W. (2009). Development and Cross-Cultural Application of a Specific Instrument to Measure Entrepreneurial Intentions. Entrepreneurship Theory and Practice, 33(3), 593-617. https://doi.org/10.1111/j.1540-6520.2009.00318.x

Lucky, E.O. (2011). Nurturing Entrepreneurship Development in the 21st Century: The Practical Approaches. International Journal of Humanities and Social Science, 1(9), 219-227.

Maes, J., Leroy, H., \& Sels, L. (2014). Gender Differences in Entrepreneurial Intentions: A TPB Multi-Group Analysis at Factor and Indicator Level. European Management Journal, 32(5), 784-794. https://doi.org/10.1016/j.emj.2014.01.001

Mat, S.C., Maat, S.M., \& Mohd, N. (2015). Identifying Factors that Affecting the Entrepreneurial Intention among Engineering Technology Students. Procedia - Social and Behavioural Sciences, 211, 1016-1022. https://doi.org/10.1016/j.sbspro.2015.11.135

Masoomi, E., Zamani, N., Bazrafkan, K., \& Reza, M. (2016). An investigation of the factor influencing entrepreneurial intention of senior agricultural students at Shiraz University, Iran. International Journal of Agricultural Management and Development, 6(4), 431-4374.

Moriano, J.A., Gorgievski, M., Laguna, M., Stephan, U., \& Zarafshani, K. (2011). A Cross-Cultural Approach to Understanding Entrepreneurial Intention. Journal of Career Development, 39(2), 162-185. https://doi.org/10.1177/0894845310384481

Muller, T. (2009). Religiosity and Attitudes Towards the Involvement of Religious Leaders in Politics: A MultilevelAnalysis of 55 Societies. World Values Research, 2(1), 1-29.

Nabila, A.S., \& Haryani, D.A.D. (2016). Determinants of Entrepreneurial Intention Among Undergraduate Students in Malaysia. Procedia Economics and Finance, 37(16), 108-114. https://doi.org/10.1016/s22125671(16)30100-9

Nejati, M., Salamzadeh, Y., \& Salamzadeh, A. (2011). Ecological purchase behaviour: insights from a Middle Eastern country. Int. J. Environment and Sustainable Development, 10(4), 417-432. https://doi.org/10.1504/IJESD.2011.047774 
Patricia, P., \& Silangen, C. (2016). The Effect of Entrepreneurship Education on Entrepreneurial Intention in Indonesia. DeReMa Jurnal Manajemen, 11(1), 67-86. https://doi.org/10.19166/derema.v11i1.184

Pearce II, J.A., Fritz, D.A., \& Davis, P.S. (2009). Entrepreneurial Orientation and the Performance of Religious Congregations as Predicted by Rational Choice Theory. Journal of Entrepreneurship Theory \& Practice, 34(1), 219-248. https://doi.org/10.1111/j.1540-6520.2009.00315.x

Ramayah, T., Cheah, J., Chuah, F., Ting, H., \& Memon, M.A. (2018). Partial Least Square Structural Equation Modelling (PLS-SEM) using SmartPLS 3.0 (2nd ed.). Kuala Lumpur, Malaysia: Pearson Malaysia.

Ridha, R.N., \& Wahyu, B.P. (2017). Entrepreneurship Intention in Agricultural Sector of Young Generation in Indonesia. Asia Pacific Journal of Innovation and Entrepreneurship, 11(1), 76-89. https://doi.org/10.1108/apjie-04-2017-022

Robledo, J.L.R., Araan, M.V., Sanchez, V.M., \& Molina, M.A. (2015). The Moderating Role of Gender on Entrepreneurial Intentions: a TPB Perspective. Omnia Science, 11(1), 92-117.

Rokhman, W., \& Ahamed, F. (2015). The Role of Social and Psychological Factors on Entrepreneurial Intention among Islamic College Students in Indonesia. Entrepreneurial Business and Economics Review, 3(1), 29-42. https://doi.org/10.15678/EBER.2015.030103

Saheed, A., \& Kavoos, M. (2016). The Present Attitude of African Youth Towards Entrepreneurship. International Journal of Small Business and Entrepreneurship Research, 4(1), 21-38. Retrieved from https://www.researchgate.net/publication/304462804_The_Present_Attitude_of_African_youth_towards_Entrepreneurship on August 20, 2020.

Salimath, M.S., \& Cullen J.B. (2010). Formal and informal institutional effects on entrepreneurship: a synthesis of nation- level research. International Journal of Organizational Analysis, 18(3), 358-385. https://doi.org/10.1108/19348831011062175

Shinnar, R.S., Giacomin, O., \& Janssen, F. (2012). Entrepreneurial Perceptions and Intentions: The Role of Gender and Culture. Entrepreneurship Theory \& Practice, 36(3), 465-493. https://doi.org/10.1111/j.15406520.2012.00509.x

Shiri, N., Davoud, M., \& Seyed, H. (2012). Entrepreneurial Intention of Agricultural Students: Effects of Role Model, Social Support, Social Norms and Perceived Desirability. Archives of Applied Science Research, 4(2), 892-897.

Soon, K., Rahman, A., \& Nadia, N. (2016). Theory of Planned Behavior: Undergraduates' Entrepreneurial Motivation and Entrepreneurship Career Intention at a Public University. Journal of Entrepreneurship: Research \& Practice, 1-14. 792385. https://doi.org/10.5171/2016.792385

Tkachev, A., \& Kolvereid, L. (1999). Self-Employment Intentions Among Russian Students. Entrepreneurship \& Regional Development, 11(3), 269-280.

Tung, L.C. (2012). The Impact of Entrepreneurship Education on Entrepreneurial Intention of Engineering Students. City University of Hong Kong.

Turker, D., \& Selcuk, S.S. (2009). Which factors affect entrepreneurial intention of university students?. Journal of European Industrial Training, 33(2), 142-159. https://doi.org/10.1108/03090590910939049

Valliere, D. (2008). Exploring Buddhist influence on the entrepreneurial decision. International Journal of Entrepreneurial Behaviour \& Research, 14(3), 172-191. https://doi.org/10.1108/13552550810874682

Wang, L., \& Wang, L. (2015). Using Theory of Planned Behavior to Predict the Physical Activity of Children: Probing Gender Differences. Bio-Med Research International. 536904. https://doi.org/10.1155/2015/536904

Wibowo, B. (2017). Religiosity and Entrepreneurial Intention. Etikonomi, 16(2), $187-206$. https://doi.org/10.15408/etk.v16i2.4963

Wijerathna, R.M.S. (2015). Factors predicting the intention of academics of faculties of agriculture in the state universities in Sri Lanka to engage in outreach activities. Tropical Agricultural Research, 26(2), 285-293. https://doi.org/10.4038/tar.v26i2.8092

Wilson, F., Kickul, J., \& Marlino, D. (2007). Gender, Entrepreneurial Self-efficacy, and Entrepreneurial Career Intentions: Implications for Entrepreneurship Education. Entrepreneurship Theory and Practice, 31(3), 387406. https://doi.org/10.1111/j.1540-6520.2007.00179.x

Yurtkoru, E.S., Kuşcu, K.Z., \& Doğanay, A. (2014). Exploring the Antecedents of Entrepreneurial Intention on Turkish University Students. Procedia - Social and Behavioural Sciences, 150, 841-850. https://doi.org/10.1016/j.sbspro.2014.09.093 
Zamrudi, Z., \& Yulianti, F. (2020). Sculpting Factor of Entrepreneurship Among University Students in Indonesia. Entrepreneurial Business and Economics Review, 8(1), 33-49. https://doi.org/10.15678/EBER.2020.080102

Zhao, H., Seibert, S., \& Hills, G. (2005). The Mediating Role of Self-Efficacy in the Development of Entrepreneurial Intentions. Journal of Applied Psychology, 90(6), 1265-1272.

Żur, A. (2014). Exploring the Role of Inspiration in Entrepreneurship Education. Horyzonty Wychowania, 13(26), 179-194. 


\section{Authors}

The contribution of co-authors is almost equal and can be expressed as $60 \%$ for the first author and the rest is the second author. G. Baharuddin (60\%) prepared the introduction, material and methods, and results and discussion sections, while A. Ab Rahman (40\%) prepared the literature review and conclusion.

\section{Gunawan Baharuddin}

PhD student in Islamic Economics at the University of Malaya (Malaysia). He received Master's degree in economics (Universiti Kebangsaan Malaysia). So far, he has published in such journals as Advanced Science Letters, International Journal of Business, and Management Tomorrow. His research interests include poverty alleviation, Islamic financial inclusion, and youth empowerment.

Correspondence to: Gunawan Baharuddin, SE., MEc; The Department of Sharia and Economics, Academy of Islamic Studies, University of Malaya. Office: Jalan Universiti, 50603 Kuala Lumpur, Wilayah Persekutuan Kuala Lumpur, Malaysia; e-mail: gbaharuddin@gmail.com

ORCID $\odot$ http://orcid.org/0000-0003-4649-5064

\section{Asmak Ab Rahman}

Senior Lecturer at the Department of Sharia and Economics, the Academy of Islamic Studies, the University of Malaya (Malaysia). She is a member of Sharia Advisory Boards, including the AmBank Group and SME Bank. Her scientific interests include comparative economic development, takaful, islamic banking, islamic economics, and economics of waqf. She received her Bachelor's degree and Master's degree in sharia, while a PhD in islamic economics from the University of Malaya, Malaysia.

Correspondence to: Assoc. Professor. Asmak Ab. Rahman; The Department of Sharia and Economics, Academy of Islamic Studies, University of Malaya. Office: Jalan Universiti, 50603 Kuala Lumpur, Wilayah Persekutuan Kuala Lumpur, Malaysia; e-mail: asmak@um.edu.my

ORCID $\odot$ http://orcid.org/0000-0003-1406-3099

\section{Acknowledgements and Financial Disclosure}

The first author would like to thank the Indonesia Endowment Fund for Education (LPDP) for providing a scholarship for his PhD program. Both authors would like to thank the anonymous referees for their useful comments, which allowed them to increase the value of this article.

\section{Conflict of Interest}

The authors declare that the research was conducted in the absence of any commercial or financial relationships that could be construed as a potential conflict of interest.

\section{Copyright and License}

This article is published under the terms of the Creative Commons

Attribution - NoDerivs (CC BY-ND 4.0) License

http://creativecommons.org/licenses/by-nd/4.0/ 